\title{
Upregulation of CD94 on CD8+T Cells in Anterior Chamber-Associated Immune Deviation Hao $\mathrm{He}^{1}$, Peizeng Yang*2, Liqiong Jiang1, Junfeng Zhang ${ }^{1}$, Changlin Zhao', Lina Chen ${ }^{1}$, Xiaomin Lin ${ }^{1}$, Hongyan Zhou $^{1}$ and Aize Kijlstra ${ }^{3,4}$
}

Address: ${ }^{1}$ State Key Laboratory of Ophthalmology, Zhongshan Ophthalmic Center, Guangzhou, PR China, ${ }^{2}$ The First Affiliated hospital, Chongqing Medical University, Chongqing, PR China, ${ }^{3}$ Eye Research Institute Maastricht, Department of Ophthalmology, University Hospital Maastricht, Maastricht, The Netherlands and ${ }^{4}$ Animal Sciences Group, Wageningen University, Lelystad, The Netherlands

Email: Hao He - hehao3000@qq.com; Peizeng Yang* - peizengy@126.com; Liqiong Jiang - jiang_emma@163.com; Junfeng Zhang - zhangjunfeng9999@163.com; Changlin Zhao - zcl1975@sina.com; Lina Chen - docchenLn@yahoo.com; Xiaomin Lin - onisa@126.com; Hongyan Zhou - hyz010203@126.com; Aize Kijlstra - aize.kijlstra@wur.nl

* Corresponding author

Published: 25 September 2008

BMC Immunology 2008, 9:53 doi:10.1 I86/147|-2172-9-53
Received: 29 April 2008

Accepted: 25 September 2008

This article is available from: http://www.biomedcentral.com/147I-2172/9/53

(c) 2008 He et al; licensee BioMed Central Ltd.

This is an Open Access article distributed under the terms of the Creative Commons Attribution License (http://creativecommons.org/licenses/by/2.0), which permits unrestricted use, distribution, and reproduction in any medium, provided the original work is properly cited.

\begin{abstract}
Background: $\mathrm{CD}^{+}$regulatory $\mathrm{T}$ cells (Treg) have been considered to be involved in a model of ocular-induced tolerance, known as anterior chamber-associated immune deviation (ACAID). The phenotype and characteristics of CD8 $8^{+}$Treg in ACAID remain only poorly understood. Recent studies have reported that the CD94-Qa-I system is implicated in the induction of ACAID $\mathrm{CD} 8^{+}$Treg, but the functions and characteristics of $\mathrm{CD} 8^{+} \mathrm{CD} 94^{+} \mathrm{T}$ cells remain unclear.

Results: Both mRNA and protein of CD94 and NKG2A were markedly up-regulated on splenic $C D 8^{+} T$ cells of ACAID mice compared with controls. Flow cytometric analysis showed that very few $C D 8^{+} C D 94^{+} T$ cells express granzyme $B$, perforin and Foxp3. CD8 ${ }^{+} C D 94^{+} T$ cells, but not CD8 ${ }^{+}$CD94-T cells, magnetically isolated from the spleens of ACAID mice, produced large amounts of TGF-betal and exhibited suppressive activity in vitro. Neutralization of TGF-betal caused reversal of suppression mediated by $\mathrm{CD} 8^{+} \mathrm{CD} 94^{+} \mathrm{T}$ cells.

Conclusion: $\mathrm{CD} 8^{+} \mathrm{CD} 94^{+} \mathrm{T}$ cells from ACAID mice exhibited suppressive activity in association with enhanced expression of TGF-betal, suggesting that $C D 8^{+}$Treg are mainly distributed in CD94+T cell subpopulations.
\end{abstract}

\section{Background}

Injection of soluble antigens (Ag) into the anterior chamber (AC) of the eye induces systemic tolerance known as anterior chamber-associated immune deviation (ACAID). It is characterized by an antigen-specific suppression of the delayed-type hypersensitivity (DTH) response and a shift in antibody production away from complement-fixing isotypes[1,2]. At least four organs or tissues including an intact eye, spleen, thymus and sympathetic nervous system are involved in the induction of ACAID, which eventually generates two distinct regulatory $\mathrm{T}$ (Tregs) cell populations in the spleen[3]. One population of Tregs comprises $\mathrm{CD} 4+\mathrm{T}$ cells which function as afferent suppressor cells and suppress the induction of a DTH response. The other Treg cell population consists of CD8+T cells which mediate an efferent suppression and inhibit the expression of a DTH response. However, little is known about the phenotype of CD8+Tregs in ACAID. 
The CD94 molecule belongs to the C-type lectin superfamily and forms a functional heterodimer with different subtypes of NKG2 [4-6]. The CD94-NKG2 receptor was originally discovered in NK cells and subsequently found on different $\mathrm{T}$ cell subsets, especially $\mathrm{CD} 8+\mathrm{T}$ cells $[7,8]$. The ligand for these receptors was the nonclassical class I molecule, Qa-1 in mice, and its homologue HLA-E in humans [9-11]. By binding to different NKG2 subsets, CD94 could regulate the cytotoxicity and survival of NK cells and CD8 ${ }^{+} \mathrm{T}$ cells upon reaction with their ligand [12-15]. Recently, a few studies reported that CD94 was associated with the regulatory function of NK cells and CD8+T cells. Della Chiesa and coworkers[16] found that a NK cell subset expressing CD94-NKG2A in lymph nodes was capable of killing immature DC and mature DC to prevent the overactivation of DCs. Using DNA microarray analysis, Keino et al[17] compared patterns of gene expression in regulatory OT- $1 \mathrm{CD} 8{ }^{+} \mathrm{T}$ cells generated in vitro with those from nonregulatory OT- $1 \mathrm{CD} 8{ }^{+} \mathrm{T}$ cells. They found that CD94 mRNA was up-regulated in OT-1 CD8+Tregs, suggesting that CD94 may play a role in immune regulation by Tregs. Chattopadhyay et al[18] extended this study and reported that mice with deficiency of CD94-NKG2A were unable to develop ACAID, and $\mathrm{CD}^{+} \mathrm{T}$ cells from these mice did not transfer the local suppression of a DTH response. Their study indicated that the CD94 molecule is necessary for the immunosuppression mediated by $\mathrm{CD} 8{ }^{+}$Treg in ACAID. However, the suppressive mechanism and characteristics of $\mathrm{CD} 8^{+} \mathrm{CD} 94^{+} \mathrm{T}$ in ACAID remain unclear. The present study showed that CD94 was up-regulated on $\mathrm{CD} 8^{+} \mathrm{T}$ cells from the spleens of ACAID mice. Very few $\mathrm{CD} 8{ }^{+} \mathrm{CD} 94^{+} \mathrm{T}$ cells express granzyme $\mathrm{B}$, perforin and Foxp3. CD8 ${ }^{+} \mathrm{CD} 94+\mathrm{T}$ cells, but not CD8 ${ }^{+}$CD94-T cells from ACAID mice exhibited suppressive activity in association with enhanced expression of TGF-beta1. These results suggest that CD8+Treg in ACAID are mainly distributed in CD $94^{+} \mathrm{T}$ cell subpopulations.

\section{Results Upregulation of the CD94-NKG2A receptor on splenic CD8 ${ }^{+} T$ cells of ACAID mice}

RT-PCR and flow cytometry were used to investigate the expression of CD94 and NKG2A on CD8 ${ }^{+} \mathrm{T}$ cells at the mRNA and protein level during ACAID. As shown in Figure 1, mRNA of CD94 and NKG2A was detectable on CD8 ${ }^{+} \mathrm{T}$ cells in all groups, but it was significantly higher in ACAID mice as compared to immunized mice, OVA-ACinjected mice, PBS-AC-injected mice and naïve mice. The expression of these two molecules in immunized mice and OVA-AC-injected mice was also significantly higher than that observed in PBS-AC-injected mice and naïve mice. As shown in Figure 2, the frequencies of CD94 and NKG2A expression on CD8 $+\mathrm{T}$ cells from spleens were significantly higher in ACAID mice $(8.68 \%, 2.92 \%)$ compared with immunized mice $(6.0 \%, 2.2 \%)$, OVA-AC- injected mice $(5.84 \%, \quad 2.25 \%)$, PBS-AC-injected mice $(2.65 \%, 1.27 \%)$ and naïve mice $(2.56 \%, 1.21 \%)$. The OVA-AC-injected mice and immunized mice also showed significantly increased frequencies of splenic CD $8{ }^{+} \mathrm{CD} 94{ }^{+} \mathrm{T}$ and $\mathrm{CD} 8{ }^{+} \mathrm{NKG} 2 \mathrm{~A}^{+} \mathrm{T}$ cells compared with PBS-AC-injected mice and naive mice.

\section{Expression of perforin, granzyme $B$ and Foxp3 in CD8 ${ }^{+}$CD94 ${ }^{+} T$ cells was minimal}

To characterize $\mathrm{CD} 8{ }^{+} \mathrm{CD} 94+\mathrm{T}$ cells, we examined the intracellular expression of granzyme $\mathrm{B}$, perforin and Foxp3. As shown in Figure 3, the expression of intracellular granzyme B, perforin and Foxp3 in fresh CD $8{ }^{+} \mathrm{CD} 94^{+} \mathrm{T}$ cells was minimal( $\sim 0.04 \%, \sim 0.01 \%$ and $\sim 0.01 \%)$ in ACAID mice, immunized mice, PBS-AC-injected mice and naïve mice. There was no significant difference among different groups.

\section{CD8 ${ }^{+} C D 94^{+} T$ cells from ACAID mice exhibited suppressive activity in vitro}

Splenic CD8 ${ }^{+} \mathrm{CD} 94+\mathrm{T}$ and $\mathrm{CD} 8+\mathrm{CD} 94-\mathrm{T}$ cells were magnetically sorted from ACAID mice and immunized mice and were shown to be over $90 \%$ pure (Fig. 4A). Purified $\mathrm{CD} 8^{+} \mathrm{CD} 94^{+} \mathrm{T}$ cells from two groups displayed hyporesponsiveness to stimulation with anti-CD3 $\mathrm{mAb}$, whereas CD8 ${ }^{+}$CD 94-T cells proliferated strongly (Fig. 4B). We next investigated whether these two subsets had suppressive effect on the proliferation of responder cells when exposed to OVA and anti-CD3 mAb in vitro. As shown in Figure $4 \mathrm{C}, \mathrm{CD} 8{ }^{+} \mathrm{CD} 94^{+} \mathrm{T}$ cells, but not $\mathrm{CD} 8{ }^{+} \mathrm{CD} 94-\mathrm{T}$ cells, from ACAID mice showed a significantly suppressive effect on the proliferation of splenic mononuclear cells (MNC) from mice with conventional immunization in a dose-dependent manner. However, both $\mathrm{CD} 8{ }^{+} \mathrm{CD} 94^{+} \mathrm{T}$ cells and $\mathrm{CD} 8{ }^{+} \mathrm{CD} 94-\mathrm{T}$ cells from immunized group did not exhibit this suppression. Additionally, OVA-ACinduced $\mathrm{CD} 8{ }^{+} \mathrm{CD} 94^{+} \mathrm{T}$ cells did not influence the proliferation of splenic MNC from naive mice when exposed to the anti-CD3 mAb stimulation (Fig. 4D).

\section{Suppressive activity of $C D 8^{+} \mathrm{CD94}+\mathrm{T}$ cells in ACAID was associated with TGF-betal production}

An ELISA was used to measure IL-10 and TGF-beta1 in the supernatants of the cultures containing APC, OVA, CD $8+C D 94+T$ or CD8 ${ }^{+}$CD94-T cells. The results showed that both $\mathrm{CD} 8{ }^{+} \mathrm{CD} 944^{+} \mathrm{T}$ and CD8 $8{ }^{+} \mathrm{CD} 94-\mathrm{T}$ cells in ACAID mice could equally produced a large amount of IL-10, which was significantly higher than that in mice following conventional immunization (Fig. 5A). Interestingly, CD8 ${ }^{+}$CD $94+T$ cells from ACAID mice secreted larger amounts of TGF-beta1 as compared with CD8 ${ }^{+}$CD94-T cells from these mice. TGF-beta1 production from the conventionally immunized control mice was also much lower than that observed by $\mathrm{CD} 8{ }^{+} \mathrm{CD} 94^{+} \mathrm{T}$ cells from ACAID mice (Fig. 5B). A blocking experiment with anti- 
A

\section{naive PBS a.c. OVA a.c. OVA s.c. ACAID}
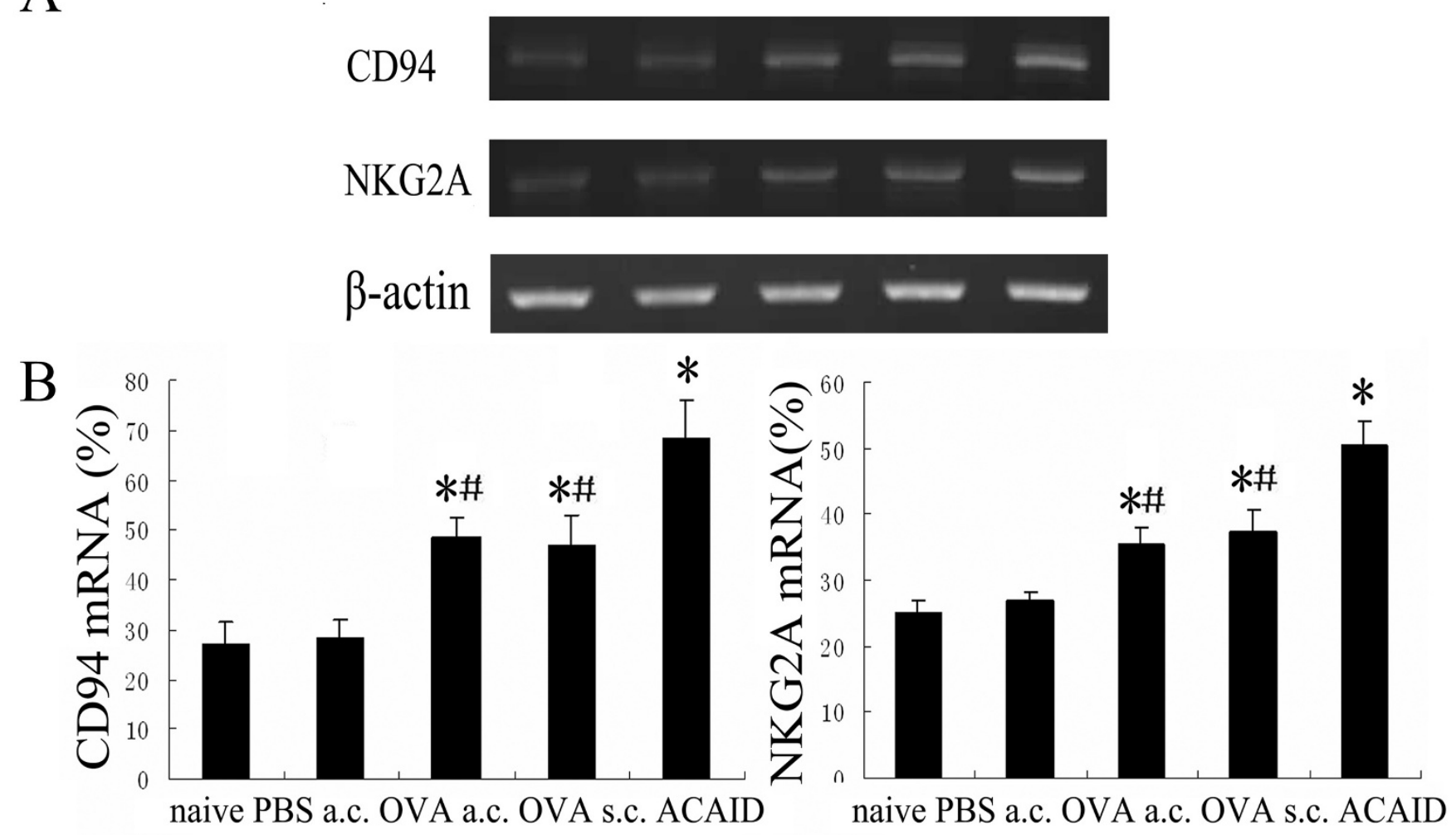

Figure I

Expression of CD94-NKG2A mRNA on CD8+T cells. Mice underwent various treatments and were divided into naïve group, PBS-AC-injected group, OVA-AC-injected group, immunized group and ACAID group. A: CD8 ${ }^{+}$T cells magnetically sorted from splenic MNC of each group were lyzed to obtain total cellular RNA using TRIzol, and RT-PCR was performed to analyze CD94 and NKG2A mRNA expression. B: histograms showed the mRNA expression (mean percentage \pm SEM) relative to $\beta$-action expression (set at $100 \%$ ). The results shown are representative of three independent experiments. ${ }^{*} \mathrm{p}<0.05$ compared with naïve mice. ${ }^{\#} p<0.05$ compared with ACAID mice.

TGF-beta1 mAb was performed to examine its influence on the cell proliferation. As shown in Figure 5C, neutralization of TGF-beta1 was able to decrease the CD8 + CD94+T cell suppressive activity by $27.4 \%$. There was still significant difference between CD8+CD94+Tuntreated group and TGF-beta1-neutralization group.

\section{Discussion}

The present study showed that expression of CD94 was up-regulated on CD8+T cells during ACAID. CD8+CD94+T cells were characterized by minimal expression of perforin, granzyme $\mathrm{B}$ and Foxp3. Furthermore the study showed that the CD8 ${ }^{+} \mathrm{CD} 94^{+} \mathrm{T}$ subpopulation from ACAID mice could significantly inhibit splenic MNC proliferation in vitro and that these cells produced large amounts of TGF-beta1. These results suggest that the $\mathrm{CD}^{+}{ }^{+} \mathrm{CD} 94^{+} \mathrm{T}$ subpopulation play a role in the immune regulation.
Although CD94 could pair with different NKG2 molecules, most CD94/NKG2 receptors on both NK and $\mathrm{CD} 8{ }^{+} \mathrm{T}$ cells have been shown to be CD94-NKG2A heterodimer in mice $[8,11]$. We first examined the expression of CD94 and NKG2A on splenic CD8+T cells. The results showed that a significantly higher expression of CD94NKG2A heterodimer on CD8+T cells was induced following OVA inoculation into the anterior chamber, and that AC-injection of antigen and immunization have a synergistic effect on the increase of $\mathrm{CD} 8+\mathrm{CD} 94+\mathrm{T}$ cells. Given the important role of cytokines in CD94-NKG2A expression [19-23], this upregulated receptor may be due to the promotion of certain cytokines from the splenic immunomodulatory microenvironment during the induction of ACAID. Interestingly, we also found an increased expression of CD94-NKG2A in mice following conventional immunization. This result is in agreement with the results presented by Jabri et al[24]. They found that CD94- 
A
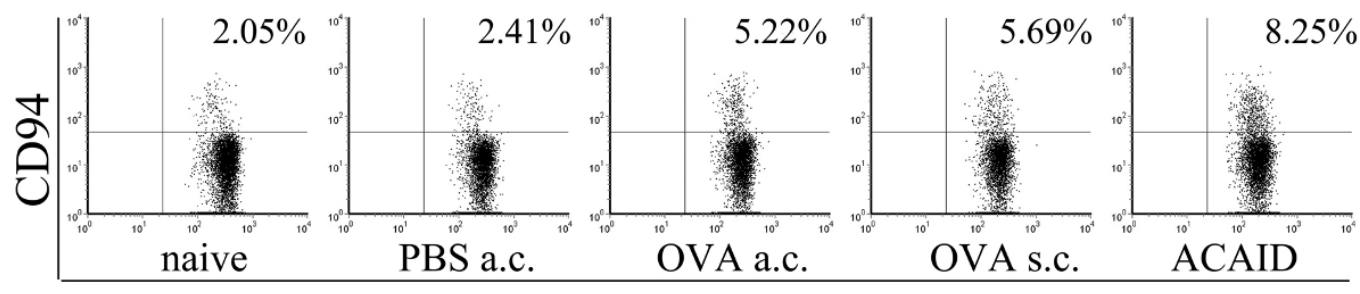

CD8
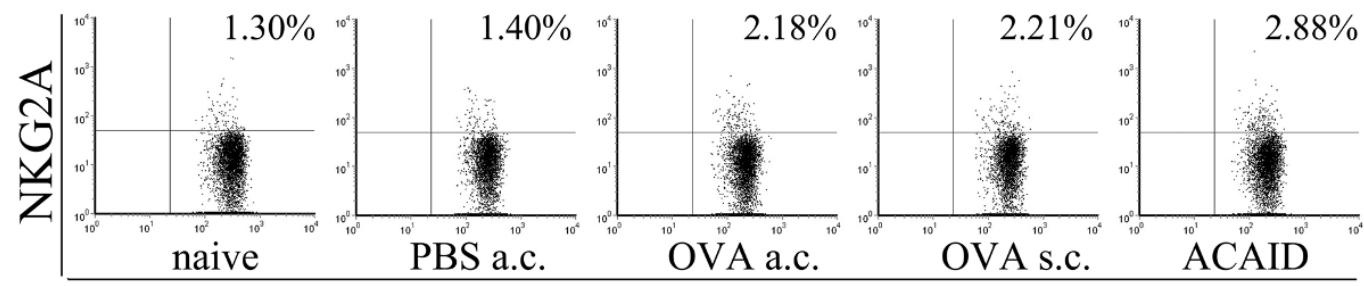

B
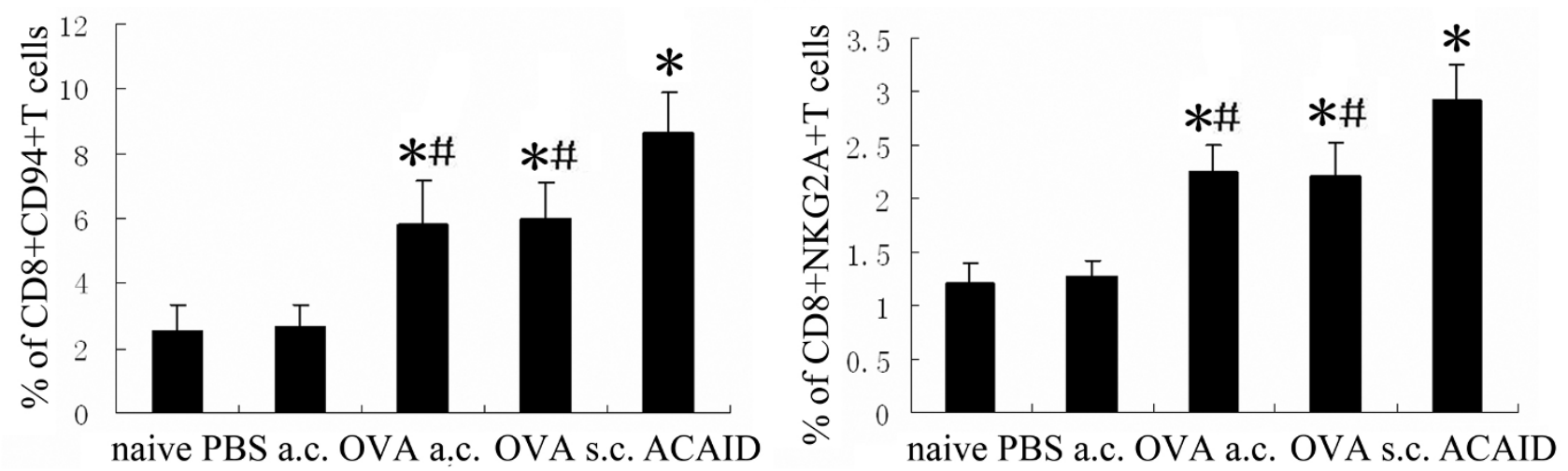

Figure 2

Expression of CD94-NKG2A protein on CD8+T cells. Mice underwent various treatments and were divided into naïve group, PBS-AC-injected group, OVA-AC-injected group, immunized group and ACAID group. A: Splenic MNC were harvested from each group and stained with anti-CD3, anti-CD8, anti-CD94 and anti-NKG2A mAb, then the CD3 ${ }^{+} \mathrm{CD} 8^{+} T$ population was gated and analyzed for the expression of CD94 and NKG2A protein. B: FCM histogram showed the frequencies of $\mathrm{CD} 8^{+} \mathrm{CD} 94^{+} \mathrm{T}$ and $\mathrm{CD} 8^{+} \mathrm{NKG} 2 \mathrm{~A}^{+} \mathrm{T}$ cells among $\mathrm{CD} 8^{+} \mathrm{T}$ cells. Results represent the mean $\pm \mathrm{SEM}$ of three separate experiments. ${ }^{*} p<0.05$ compared with naïve mice. ${ }_{p} p<0.05$ compared with ACAID mice.

NKG2A could be induced on CD8+T cells following TCRmediated activation in vivo.

It is well known that CTL, which are mainly found in the $\mathrm{CD} 8{ }^{+} \mathrm{T}$ cell subpopulation, are impaired during ACAID[25]. Analysis of the expression of perforin and granzyme B, two important molecules for cytotoxicity, on CD $8+C D 94+T$ only revealed a moderate expression. These data are consistent with an earlier study we reported, where we could not detect secretion of granzyme B by $\mathrm{CD} 8^{+} \mathrm{T}$ cells in ACAID mice, whereas production in control immunized mice was readily observed [26]. This phenomenon is also confirmed by Cone et al that perforin was not required for suppression by ACAID $\mathrm{CD} 8{ }^{+}$Treg[27]. The very low production of granzyme $\mathrm{B}$ and perforin by CD $8+C D 94+T$ cells in each group in this study suggests that these two molecules are not involved in the development of ACAID.

Although CD8 ${ }^{+} \mathrm{T}$ cells from ACAID mice exert suppres$\operatorname{sion}[28,29]$, it is unknown that which subpopulation of $\mathrm{CD} 8{ }^{+} \mathrm{T}$ cells exhibit suppressive activity. Chattopadhyay[18] et al demonstrated that DBA/2J mice, characterized by a deficiency in CD94/NKG2A, showed a defective immune regulation by $\mathrm{CD} 8{ }^{+}$Treg response in vivo following intracameral antigen inoculation. Their study supported that CD94 is necessary for the generation and function of $\mathrm{CD} 8+$ Treg, but no results about the suppressive activity of $\mathrm{CD} 8{ }^{+} \mathrm{CD} 94^{+} \mathrm{T}$ cells are showed. As both intracameral inoculation and conventional immunization could upregulate CD94-NKG2A expression, we examined the inhibitory effect of $\mathrm{CD} 8{ }^{+} \mathrm{CD} 94^{+} \mathrm{T}$ cells from ACAID 

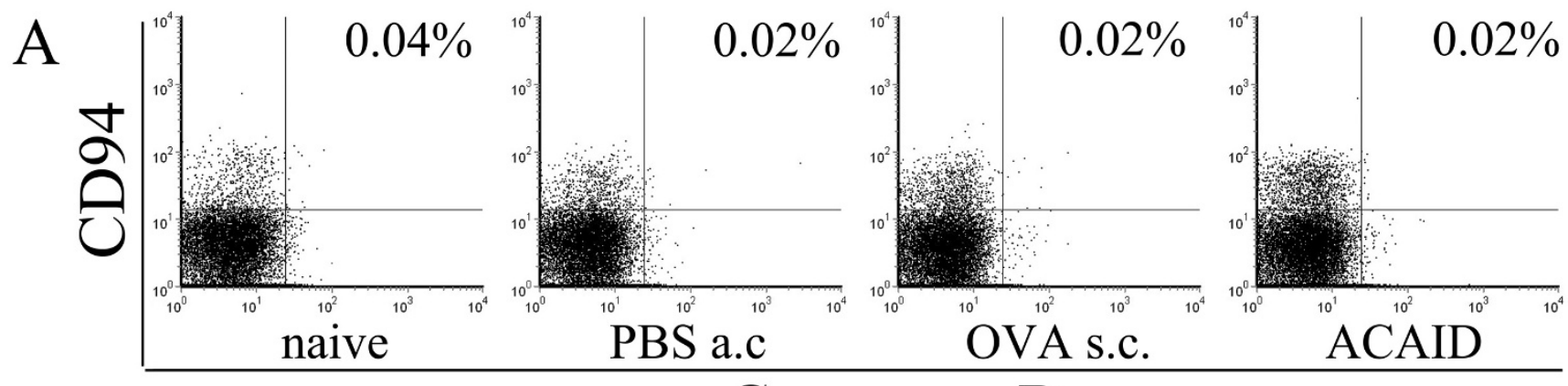

Granzyme B

B
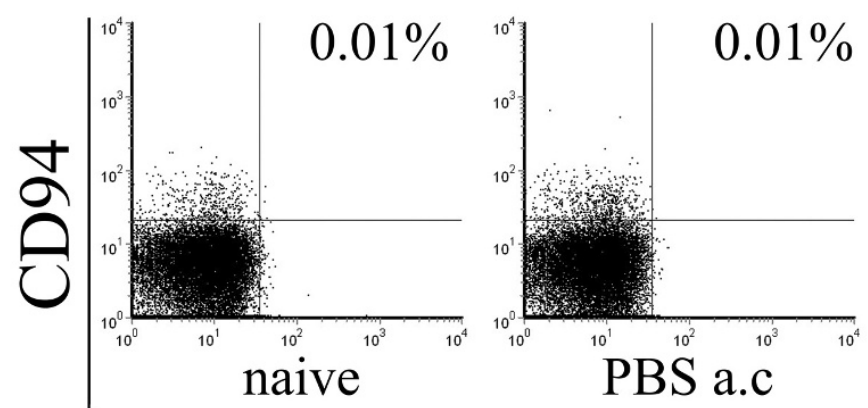

PBS a.c

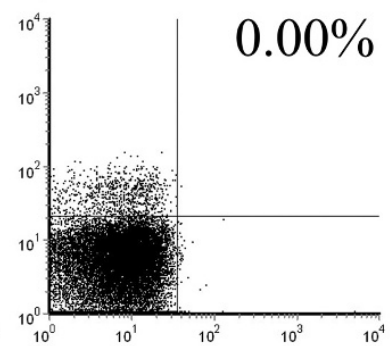

OVA s.c.

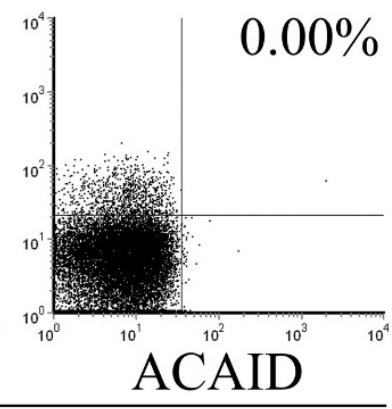

ACAID
$\mathrm{C}$

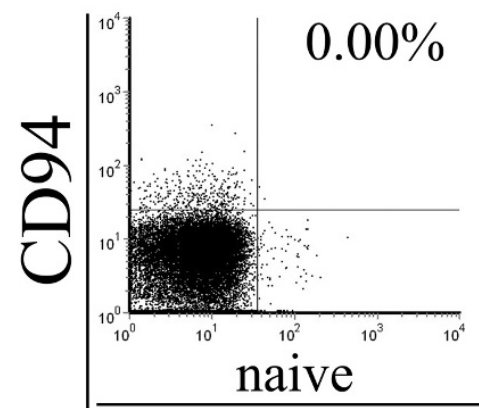

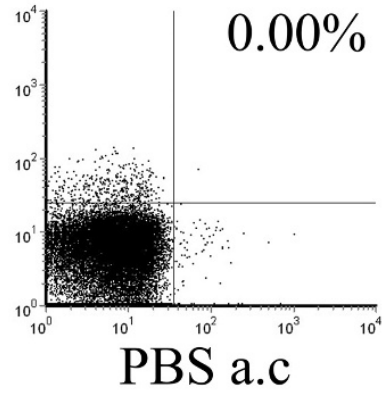
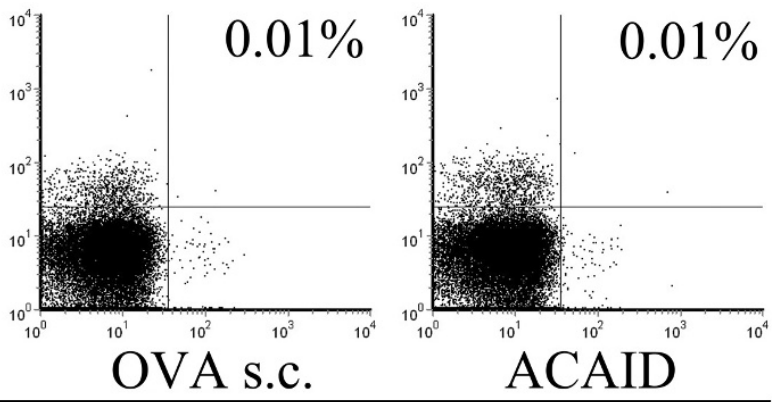

\section{Foxp3}

Figure 3

Expression of granzyme B, perforin and Foxp3 in CD8 ${ }^{+}$CD94 ${ }^{+} T$ cells. Splenic MNC from ACAID mice, immunized mice, PBS-AC-injected mice and naïve mice were prepared and labeled with anti-CD3, anti-CD8, anti-CD94, anti-perforin, anti-granzyme $B$ and anti-Foxp3 mAb. A: $C D 3^{+} C D 8^{+} T$ population was gated and analyzed for the frequency of $C D 94{ }^{+}$granzyme $\mathrm{B}^{+} \mathrm{T}$ cells. $\mathrm{B}: \mathrm{CD}^{+} \mathrm{CD} 8^{+} \mathrm{T}$ population was gated and analyzed for the frequency of $C D 94^{+}$perforin ${ }^{+} \mathrm{T}$ cells. $\mathrm{C}: \mathrm{CD}^{+} \mathrm{CD} 8^{+} \mathrm{T}$ population was gated and analyzed for the frequency of $C D 94^{+}$Foxp $3^{+} T$ cells. The results shown are representative of three independent experiments.

mice and immunized mice on the proliferation of splenic $\mathrm{MNC}$ in vitro. The results showed that only $\mathrm{CD} 8{ }^{+} \mathrm{CD} 94^{+} \mathrm{T}$ cells from ACAID mice profoundly inhibited the proliferation of responder cells, CD8 + CD94-T cells from ACAID mice as well as immunized mice showed no suppressive activity. As OVA and anti-CD3 mAb was concurrently used to stimulate MNC from the immunized mice, both antigen-specific and non-specific suppression were measured in our system. In a pilot experiment we tried to detect the antigen-specific suppression by using OVA alone. However, a weak response of MNC to antigen made it difficult to compare the result between positive and suppression groups. In contrast, we found that OVA-AC-induced $\mathrm{CD} 8{ }^{+} \mathrm{CD} 94{ }^{+} \mathrm{T}$ cells did not influence the proliferation of splenic MNC from naive mice when exposed to polyclonal stimulation, this result seems to suggest a property of antigen-specific suppression of $\mathrm{CD} 8{ }^{+} \mathrm{CD} 94^{+} \mathrm{T}$ cells in ACAID. It is consistent with the previous observations 


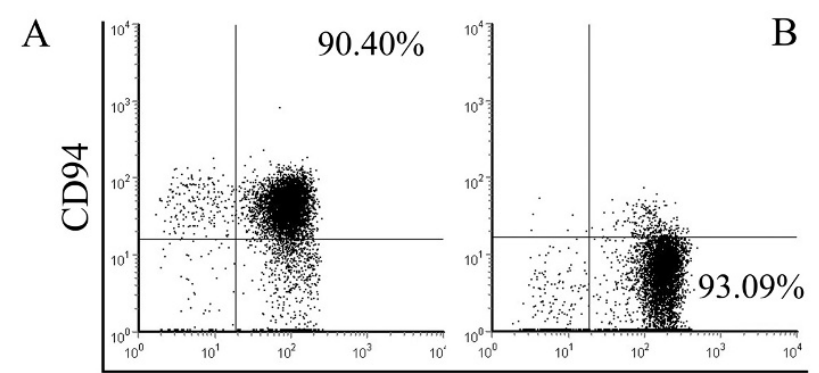

CD8

C

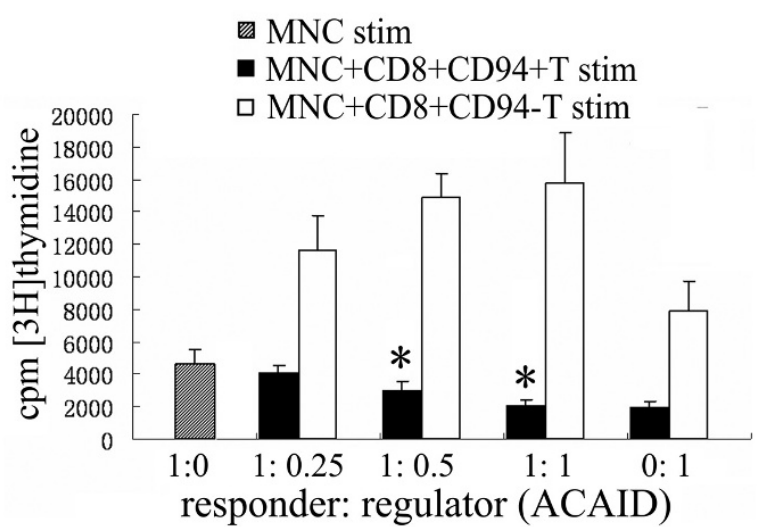

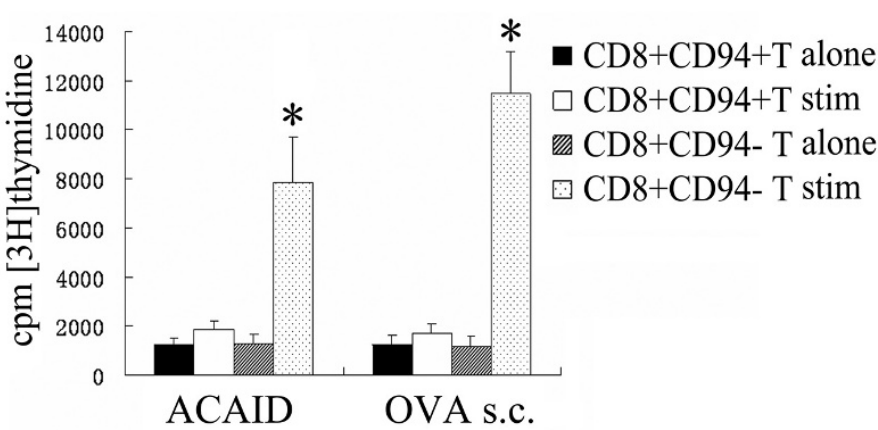

MNC stim

- $\mathrm{MNC}+\mathrm{CD} 8+\mathrm{CD} 94+\mathrm{T}$ stim

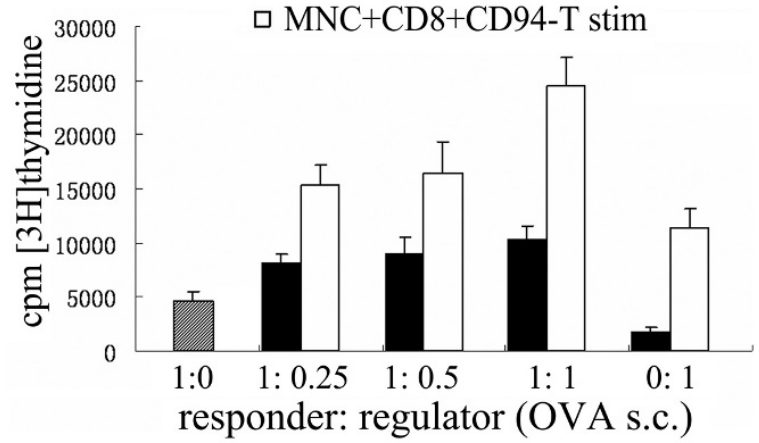

D

responders

(naive MNC)

regulators

(ACAID CD8+CD94+/-T)

stimulator

(anti-CD3 mAb)

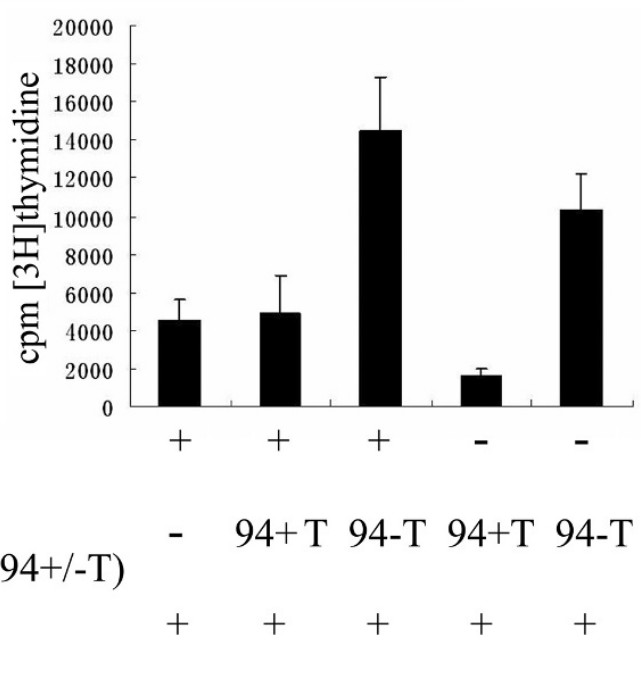

\section{Figure 4}

Suppressive activity exhibited by $C D 8^{+} C D 94^{+} T$ cells from ACAID mice in vitro. A: the purity of isolated $\mathrm{CD} 8^{+} \mathrm{CD} 94^{+} \mathrm{T}$ (left) and $\mathrm{CD} 8{ }^{+} \mathrm{CD} 94-\mathrm{T}$ (right) cells by magnetic affinity cell sorting; $\mathrm{B}$ : the response of $\mathrm{CD} 8^{+} \mathrm{CD} 94^{+} \mathrm{T}$ and CD8 ${ }^{+}$CD94-T cells to anti-CD3 mAb stimulation (stim). ${ }_{\mathrm{p}}<0.05$ compared with unstimulated group. C: suppressive effect of CD8 ${ }^{+} \mathrm{CD} 94^{+} \mathrm{T}$ and $\mathrm{CD8} 8^{+} \mathrm{CD} 94-\mathrm{T}$ cells on the proliferation of splenic MNC. Splenic MNC $\left(5 \times 10^{4} \mathrm{cells} /\right.$ well, as responder cells) from immunized mice were cocultured with purified $C D 8^{+} C D 94^{+} T$ or $C D 8^{+} C D 94-T$ cells (as regulatory cells) from ACAID mice and immunized mice at different responder/suppressor ratios $(1: 0,1: 0.25,1: 0.5$ and $I: I)$ in the presence of OVA $(100 \mu \mathrm{g} / \mathrm{ml})$ and anti-CD3 $\mathrm{mAb}(\mathrm{I} \mu \mathrm{g} / \mathrm{ml})$ for 72 hours and pulsed with $[3 \mathrm{H}]$ thymidine for the last 16 hours of culture. Data are represented as mean \pm SEM of triplicate samples. ${ }^{*}$ < 0.05 compared with stimulated MNC group. D: suppressive effect of $C D 8^{+} C D 94{ }^{+} T$ and $C D 8^{+} C D 94-T$ cells from ACAID mice on the proliferation of splenic MNC from naive mice (at I:I ratio) upon anti-CD3 $\mathrm{mAb}(\mathrm{I} \mu \mathrm{g} / \mathrm{ml})$ stimulation. 
A

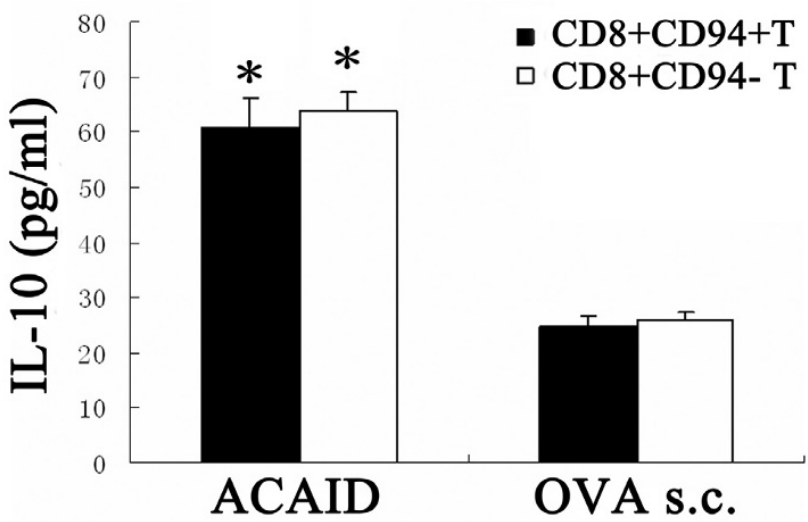

B

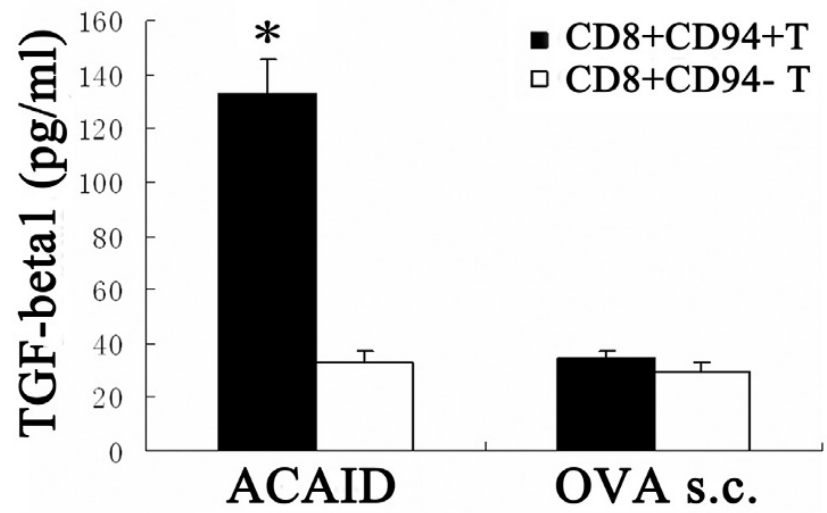

C
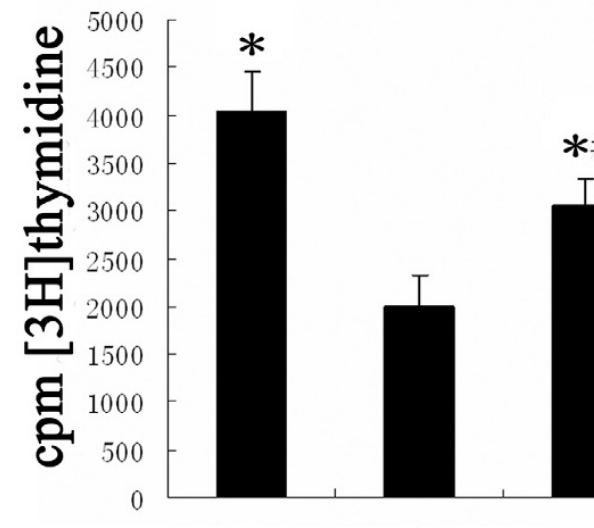

stimulated MNC

$+$

$+$

$+$

*\#

CD8+CD94+T

anti-TGF beta1

isotype

- -

$+\quad+$

$\begin{array}{lll}- & -\end{array}$

$+\quad-$

Figure 5

IL- 10 and TGF-betal production and the role of TGF-betal in immunosuppression. CD8 ${ }^{+} C D 94^{+} T$ or $C D 8^{+} C D 94-$ T cells $\left(5 \times 10^{4}\right)$ from ACAID mice and immunized mice were cocultured with PEC $\left(I \times 10^{5}\right)$ and OVA $(100 \mu g / \mathrm{ml})$ for 72 hours. ELISA was used to detect the concentration of IL-I0 (A) and TGF-betal (B) in the supernatants of the cultures. *p < 0.05 compared with immunized mice. For blocking experiments (C), anti-TGF-betal $\mathrm{mAb}(50 \mu \mathrm{g} / \mathrm{ml})$ or matched isotype was added to the culture at the initiation of the cell proliferation assay, then $[3 \mathrm{H}]$ thymidine incorporation was measured to value the suppressive activity of $\mathrm{CD8}{ }^{+} \mathrm{CD} 94^{+} \mathrm{T}$ cells from ACAID mice. Data are represented as mean \pm SEM of triplicate samples. $*_{p}<0.05$ compared with stimulated $M N C+C D 8{ }^{+} C D 94{ }^{+} T$ cell group (the second bar). ${ }_{p} p 0.05$ compared with stimulated MNC group (the first bar). 
that CD8 $+\mathrm{T}$ cells in ACAID are efferent antigen-specific Tregs. Another property of CD8 $8+\mathrm{CD} 94+\mathrm{T}$ cells was hypoproliferation when stimulated with polyclonal stimulation, this anergic state of $\mathrm{CD} 8{ }^{+} \mathrm{CD} 94^{+} \mathrm{T}$ cells was similar to other Tregs such as CD4+CD25+Treg[30,31]. However, CD8 ${ }^{+}$CD94-T cells did not show any suppressive activity and anergy, suggesting the non-Treg's property of these cells. These data suggest that the induced expression of CD94 molecule is associated with the inhibitory effect of $\mathrm{CD} 8{ }^{+} \mathrm{T}$ cells following OVA inoculation into the anterior chamber.

It is interesting that $\mathrm{CD} 8{ }^{+} \mathrm{CD} 94^{+} \mathrm{T}$ cells from ACAID mice, but not from immunized mice exert suppression in vitro. What results in the different suppressive activity of $\mathrm{CD} 8{ }^{+} \mathrm{CD} 94^{+} \mathrm{T}$ cells between tolerant mice and immunized mice? As cells exert their function mainly through releasing cytokines or contacting the target cells, it is possible that different cytokine secretion may cause different functional effects. IL-10 and TGF-beta have been shown to be the suppressive cytokines of CD8+Treg in some models [32-39]. Wang and collaborators found that an increased IL-10 and TGF-beta2 were observed in the cultures containing AC-splenic T cells, lymph node cells and antigen[28]. Kezuka et al[40] demonstrated that TGF-beta2 is not required for the suppression mediated by in vitro-activated OT-1 Treg, similar to ACAID CD8+Treg. We subsequently analyzed the production of TGF-beta1 and IL-10 to evaluate the association of these inhibitory cytokines with suppressive property of $\mathrm{CD} 8+\mathrm{CD} 94+\mathrm{T}$ cells. Our result showed that $\mathrm{CD} 8+\mathrm{CD} 94+\mathrm{T}$ cells from ACAID mice produced larger amounts of TGF-beta1 and IL-10 than those from conventionally immunized mice, suggesting that different cytokine secretion is associated with different inhibitory property. It is interesting to note that there was no difference between $\mathrm{CD} 8{ }^{+} \mathrm{CD} 94^{+} \mathrm{T}$ cells and $\mathrm{CD} 8{ }^{+} \mathrm{CD} 94-\mathrm{T}$ cells concerning IL-10 production. The unique increased TGF-beta 1 production by the CD $8{ }^{+} \mathrm{CD} 94^{+} \mathrm{T}$ cells with suppressive activity in ACAID mice raises a question as to whether these cells exert their role via TGF-beta1. Our further experiment using antiTGF-beta1 antibody tested this possibility and found that it could partially block the inhibitory activity of $\mathrm{CD} 8{ }^{+} \mathrm{CD} 94^{+} \mathrm{T}$ cells. The anti-TGF-beta 1 antibody has been titrated to test whether it could completely neutralize its inhibition. Even higher concentrations still showed a partial inhibition (data not shown). It has been demonstrated that different subpopulations of $\mathrm{CD} 8^{+}$Treg exert their immunosuppression possibly by different mechanisms. There may be other factors involved in this inhibition, for instance cell-cell contact, other isoforms of TGFbeta or other cytokines. More studies are needed to clarify these issues.
Given the different suppressive activity between CD $8{ }^{+C D} 94{ }^{+} \mathrm{T}$ and $\mathrm{CD} 8{ }^{+} \mathrm{CD} 94-\mathrm{T}$ cells in ACAID mice, we thinks that $\mathrm{CD} 8+$ Treg are mainly distributed in CD94+T subpopulation in ACAID. However, it appears that CD94 is not a specific marker for CD8+Treg, as this molecule can be upregulated following $\mathrm{T}$ cell activation and CD8 ${ }^{+C D} 94+T$ cells from immunized mice did not show suppression. This phenomenon resembles the role of CD25, CTLA-4 and GITR in identifying CD4+Treg. What is the specific marker for CD8+Treg? Recent studies reported that one population of CD8+Tregs was associated with Foxp3 expression [41-43], we further examined the expression of Foxp3 by CD $8+C D 94+T$ cells. Our data showed that very few CD8+CD94+T cells expressed Foxp3 and there was no significant difference among different experimental groups. Earlier studies from our group also showed a very low expression of Foxp 3 by CD8 ${ }^{+} \mathrm{T}$ cells, but the frequency of $\mathrm{CD}^{+}{ }^{+} \mathrm{Foxp}^{+}{ }^{+}$cells in splenocytes of ACAID mice was upregulated following polyclonal or specific antigen stimulation in vitro[29]. In the present study, splenocytes were not treated with any stimulation, which may explain why we did not detect any significant difference in Foxp3 expression among the different groups. Our results support the opinion provided by Ahmadzadeh et al[44] that Foxp3 can not be simply interpreted as an indicator of Treg activity. Our study also suggests that $\mathrm{CD} 8{ }^{+} \mathrm{CD} 94^{+} \mathrm{T}$ cells may be only one population of CD8 ${ }^{+}$ Treg.

\section{Conclusion}

The data presented in this paper showed that CD8 ${ }^{+} \mathrm{CD} 94+\mathrm{T}$ cells from ACAID mice exhibited suppressive activity in association with enhanced expression of TGF-beta1, suggesting CD8+Treg may be mainly distributed in CD94+T subpopulation in ACAID. However, it appears that CD94 is not a specific marker for CD8+Treg, because this molecule is associated with $\mathrm{CD} 8+\mathrm{T}$ cell activation and no suppression was observed by $\mathrm{CD} 8{ }^{+} \mathrm{CD} 94^{+} \mathrm{T}$ cells from immunized mice. There are also some limitations in our study. The profile of cytokines by CD8 ${ }^{+}{ }^{C D} 94+T$ remains unclear. Due to the low number of CD $8{ }^{+} \mathrm{CD} 94^{+} \mathrm{T}$ cells from ACAID mice, we were not able to perform adoptive transfer experiments. More studies using more sensitive techniques and more experiments are needed to clarify the role of $\mathrm{CD} 8{ }^{+} \mathrm{CD} 94^{+} \mathrm{T}$ cells in the development of ACAID. As NKT cells may be positive for both CD8 and CD94 molecules [45-47], the isolated $\mathrm{CD} 8{ }^{+} \mathrm{CD} 94^{+} \mathrm{T}$ cells in this study may contain NKT cells.

\section{Methods \\ Mice}

Female C57BL/6 (B6; H-2b) mice, 6 to 8 weeks of age, were purchased from the animal facility at the Sun Yat-Sen University, P.R. China. All mice were treated according to 
the ARVO Statement for the Use of Animals in Ophthalmic and Vision Research.

\section{Induction of ACAID}

ACAID was induced as described previously using microinjection of antigen into the AC of the eye[48]. Briefly, mice were anesthetized with inhalation anesthesia consisting of oxygen and 1.7\% isoflurane followed by injection of $5 \mu \mathrm{l}$ ovalbumin at $20 \mathrm{mg} / \mathrm{ml}$ (OVA, Sigma, St. Louis, MO) into the AC by a glass micropipette with a sterile infant feeding tube mounted onto a $0.1 \mathrm{ml}$ Hamilton (Hamilton, Reno, NV) syringe. Seven days later, mice received a subcutaneous (s.c.) immunization with $250 \mu \mathrm{g}$ OVA dissolved in PBS and emulsified in complete Freund's adjuvant (Life Technologies, Grand Island, NY). Mice only receiving subcutaneous injections of OVA in CFA were used as immunized controls (OVA s.c.). Mice receiving an AC-injection of $5 \mu$ l sterile PBS alone served as PBS-AC-injected controls (PBS a.c.). Mice receiving an AC-injection of $5 \mu$ l OVA without subsequent immunization served as OVA-AC-injected controls (OVA a.c.).

\section{Preparation of peritoneal exudate cells}

Peritoneal exudate cells (PECs) were obtained from normal $\mathrm{C} 57 \mathrm{BL} / 6$ mice that received $2 \mathrm{ml}$ of thioglycolate (Sigma Chemical Co.) intraperitoneally three days earlier. Briefly, the recovered cells were washed and resuspended, placed in a 24 -well culture plate $\left(1 \times 10^{6} /\right.$ well $)$, and incubated in complete RPMI 1640 medium at $37^{\circ} \mathrm{C}$ in an atmosphere of $5 \% \mathrm{CO}_{2}$. After overnight culture, plates were washed three times with culture medium to remove nonadherent cells. Adherent cells were retained in the wells and used as antigen-presenting cells (APC). More than $90 \%$ of these adherent cells were F4/80+ as identified by subsequent FCM analysis.

\section{Reverse transcription-PCR}

Total cellular RNA was isolated from $5 \times 10^{6}$ freshly purified splenic $\mathrm{CD} 8+\mathrm{T}$ cells of the experimental and control mice using Trizol (Invitrogen, San Diego, CA). Singlestrand cDNA was synthesized with an RT-PCR kit (Qiagen, Hilden, Germany) according to the manufacturer's instructions. The following primers were used: CD94-FW, 5'-TTTCTTGATGGTTACTTTGGGAGTT-3'; CD94-RV, 5'AAACGCTTTTGCTTGGACTGTA-3'; NKG2A-FW, 5'CAGTCATCGAGCAGGAAATC-3'; NKG2A-RV， 5'-GCTGACCTCTGCCCTTCCGA-3'; $\beta$-actin-FW, 5'-GTCCCTCACCCTCCCAAAAG-3'; $\quad \beta$-actin-RV, $5 '$ GCTGCCTCAACACCTCAACCC-3'. PCR was performed with a initially heating to $94^{\circ} \mathrm{C}$ for 5 min followed by 30 cycles at $94^{\circ} \mathrm{C}$ for $30 \mathrm{~s}, 60^{\circ} \mathrm{C}$ for $30 \mathrm{~s}$, and $72^{\circ} \mathrm{C}$ for $60 \mathrm{~s}$. Splenocytes from four mice were used in each group in one experiment. The experiment was repeated three times.

\section{Flow cytometry}

For cell surface staining, splenocytes $\left(1 \times 10^{6}\right)$ were stained with FITC or PE-Cy7-anti-CD3 mAb, APC or FITC antiCD8 mAb, PE anti-CD94 mAb, PE-anti-NKG2A mAb for 30 minutes at $4^{\circ} \mathrm{C}$ in the dark. For intracellular cytokine staining, cells were first stained for surface markers followed by fixation and permeabilization, and were then stained with APC-anti-perforin mAb, FITC-anti-granzyme $\mathrm{B} \mathrm{mAb}$, APC-anti-Foxp3 mAb or matched isotypes according to the manufacturer's instructions. Phenotypic analysis was performed on a BD FACSAria(BD Biosciences, San Jose, CA) using the BD FACSDiVa software (BD Biosciences). All conjugated antibodies were purchased from eBioscience(San Diego, CA). Four mice were used for each group in one experiment. These experiments were repeated three times.

\section{Magnetic affinity cell sorting}

Splenic mononuclear cells (MNC) were prepared by density gradient centrifugation. $\mathrm{CD}^{+} \mathrm{T}$ cells were purified from splenic MNC of C57BL/6 mice by negative selection using a CD8+T-cell isolation kit (Miltenyi Biotec, Auburn, CA) according to the manufacture's instructions. Enriched $\mathrm{CD}^{+} \mathrm{T}$ cells were stained with PE-conjugated anti-mouse CD94 mAb (eBioscience, San Diego, CA) for 30 minutes at $4{ }^{\circ} \mathrm{C}$ in the dark followed by anti-PE microbeads (Miltenyi Biotec) for 15 minutes at $4^{\circ} \mathrm{C}$. A positive selection was performed and both $\mathrm{CD} 8^{+} \mathrm{CD} 94^{+} \mathrm{T}$ and CD8 ${ }^{+} \mathrm{CD} 94-\mathrm{T}$ cells were isolated as described by the manufacturer. The purity of $\mathrm{CD} 8+\mathrm{CD} 94+\mathrm{T}$ and $\mathrm{CD} 8+\mathrm{CD} 94-\mathrm{T}$ cells was $>90 \%$ as determined by subsequent FCM analysis.

\section{Proliferation and cytokine assays}

Splenic MNC (5 × $10^{4}$ cells/well, as responder cells $)$ from immunized mice were cocultured with purified CD8 ${ }^{+} \mathrm{CD} 94^{+} \mathrm{T}$ or $\mathrm{CD} 8{ }^{+} \mathrm{CD} 94-\mathrm{T}$ cells (as regulatory cells) from ACAID mice and immunized mice at different responder/suppressor ratios $(1: 0,1: 0.25,1: 0.5,1: 1)$ in the presence or absence of $\mathrm{OVA}(100 \mu \mathrm{g} / \mathrm{ml})$ and anti-CD3 $\mathrm{mAb}(1 \mu \mathrm{g} / \mathrm{ml})$ (eBioscience, San Diego, CA) for 72 hours and pulsed with $[3 \mathrm{H}]$ thymidine (Shanghai Institute of Applied Physics, Chinese Academy of Sciences, China) for the last 16 hours of culture. [3H]thymidine incorporation was determined by scintillation spectrometry. The suppressive effect of CD8 + CD94+T and CD8+CD94-T cells from ACAID mice on the proliferation of splenic MNC from naive mice (at 1:1 ratio) upon anti-CD3 $\mathrm{mAb}(1 \mu \mathrm{g} /$ $\mathrm{ml}$ ) stimulation was examined. In addition, the proliferation of $\mathrm{CD}^{+}{ }^{+\mathrm{CD} 94} 4^{+\mathrm{T}}$ and $\mathrm{CD} 8{ }^{+} \mathrm{CD} 94-\mathrm{T}$ cells $\left(5 \times 10^{4}\right.$ cells/well) from ACAID mice and immunized mice to the polyclonal stimulation was also examined. In order to clarify whether TGF-beta1 has an effect on suppression mediated by CD8 ${ }^{+} \mathrm{CD} 94^{+} \mathrm{T}$ cells from ACAID mice, additional proliferation assays were performed after blocking 
with anti-TGF beta1 mAb or matched isotype(R\&D Systems, Inc, USA). Proliferation data were expressed as mean $\mathrm{cpm} \pm$ SEM of triplicate reactions. To detect IL-10 and TGF-beta1 production, freshly isolated splenic CD8 ${ }^{+} \mathrm{CD} 94+\mathrm{T}$ or CD8+CD94-T cells from various groups of mice were cultured in the 96-well plates containing PECs $\left(1 \times 10^{5} /\right.$ well $)$ and $\operatorname{OVA}(100 \mu \mathrm{g} / \mathrm{ml})$ for 72 hours. Supernatants were collected and assayed by ELISA (R\&D system, Minneapolis, MN, USA) according to the manufacturer's instructions. Four mice were used for each group in one experiment. The experiment was repeated three times.

\section{Statistical analyses}

All statistical analyses were performed by ANOVA using SPSS 11.0. A value of $\mathrm{p}<0.05$ was considered significantly different.

\section{Authors' contributions}

$\mathrm{HH}$ carried out the whole studies and drafted the manuscript. PY was responsible for the overall design and execution of the experimental program. LJ and JZ were responsible for induction of ACAID. CZ and LC participated in the flow cytometric analysis and ELISA. XL and HZ performed in PT-PCR and cell proliferation assay. AK contributed to date interpretation and manuscript revision. All authors have read and approved the final manuscript.

\section{Acknowledgements}

The authors thank Prof. Dr. Changyou Wu for his constructive suggestions. This study is supported by the Key Project of Natural Science Foundation (30630064); Natural Science Foundation for Research Groups of Guangdong Province (05200176); Project of science and technology of Guangdong Province (2005B60302009); Project of International Cooperation in Science and Technology, Guangdong Province (2006A5010700I) and National Natural Science Foundation(30572004).

\section{References}

I. Stein-Streilein J, Streilein JW: Anterior chamber associated immune deviation (ACAID): regulation, biological relevance, and implications for therapy. Int Rev Immunol 2002, 2I: $123-152$.

2. Niederkorn JY: The induction of anterior chamber-associated immune deviation. Chem Immunol Allergy 2007, 92:27-35.

3. Wilbanks GA, Streilein JW: Characterization of suppressor cells in anterior chamber-associated immune deviation (ACAID) induced by soluble antigen. Evidence of two functionally and phenotypically distinct T-suppressor cell populations. Immunology 1990, $71: 383-389$.

4. Carretero M, Cantoni C, Bellon T, Bottino C, Biassoni R, Rodriguez A, Perez-Villar JJ, Moretta L, Moretta A, Lopez-Botet M: The CD94 and NKG2-A C-type lectins covalently assemble to form a natural killer cell inhibitory receptor for HLA class I molecules. Eur J Immunol 1997, 27:563-567.

5. Cantoni C, Biassoni R, Pende D, Sivori S, Accame L, Pareti L, Semenzato G, Moretta L, Moretta A, Bottino C: The activating form of CD94 receptor complex: CD94 covalently associates with the Kp39 protein that represents the product of the NKG2C gene. Eur J Immunol 1998, 28:327-338.

6. Lazetic S, Chang C, Houchins JP, Lanier LL, Phillips JH: Human natural killer cell receptors involved in MHC class I recognition are disulfide-linked heterodimers of CD94 and NKG2 subunits. J Immunol 1996, I 57:474I-4745.

7. Moretta A, Biassoni R, Bottino C, Pende D, Vitale M, Poggi A, Mingari MC, Moretta L: Major histocompatibility complex class I-specific receptors on human natural killer and $\mathbf{T}$ lymphocytes. Immunol Rev 1997, 155:105-II7.

8. Lohwasser S, Kubota A, Salcedo M, Lian RH, Takei F: The non-classical MHC class I molecule Qa-I(b) inhibits classical MHC class I-restricted cytotoxicity of cytotoxic T lymphocytes. Int Immunol 200I, I 3:321-327.

9. Vance RE, Kraft JR, Altman JD, Jensen PE, Raulet DH: Mouse CD94/ NKG2A is a natural killer cell receptor for the nonclassical major histocompatibility complex (MHC) class I molecule Qa-I(b). J Exp Med I998, I 88: |84|-1848.

10. Braud VM, Allan DS, O'Callaghan CA, Soderstrom K, D'Andrea A, Ogg GS, Lazetic S, Young NT, Bell JI, Phillips JH, Lanier LL, McMichael AJ: HLA-E binds to natural killer cell receptors CD94/ NKG2A, B and C. Nature 1998, 391:795-799.

II. Vance RE, Jamieson AM, Raulet DH: Recognition of the class Ib molecule Qa-I(b) by putative activating receptors CD94/ NKG2C and CD94/NKG2E on mouse natural killer cells. J Exp Med 1999, 190:1801-1812.

12. Suvas S, Azkur AK, Rouse BT: Qa-Ib and CD94-NKG2a interaction regulate cytolytic activity of herpes simplex virus-specific memory CD8+ T cells in the latently infected trigeminal ganglia. J Immunol 2006, I76:I703-I7II.

13. Gunturi A, Berg RE, Forman J: Preferential survival of CD8 T and NK cells expressing high levels of CD94. J Immunol 2003, I 70: I737-I745.

14. Houchins JP, Lanier LL, Niemi EC, Phillips JH, Ryan JC: Natural killer cell cytolytic activity is inhibited by NKG2-A and activated by NKG2-C. J Immunol 1997, I 58:3603-3609.

15. Le Drean E, Vely F, Olcese L, Cambiaggi A, Guia S, Krystal G, Gervois $\mathrm{N}$, Moretta A, Jotereau F, Vivier E: Inhibition of antigen-induced $T$ cell response and antibody-induced NK cell cytotoxicity by NKG2A: association of NKG2A with SHP-I and SHP-2 protein-tyrosine phosphatases. Eur J Immunol 1998, 28:264-276.

16. Della Chiesa M, Vitale M, Carlomagno S, Ferlazzo G, Moretta L, Moretta A: The natural killer cell-mediated killing of autologous dendritic cells is confined to a cell subset expressing CD94/NKG2A, but lacking inhibitory killer Ig-like receptors. Eur J Immunol 2003, 33: 1657-1666.

17. Keino H, Masli S, Sasaki S, Streilein JW, Stein-Streilein J: CD8+ T regulatory cells use a novel genetic program that includes CDIO3 to suppress ThI immunity in eye-derived tolerance. Invest Ophthalmol Vis Sci 2006, 47:I533-I542.

18. Chattopadhyay S, O'Rourke J, Cone RE: Implication for the CD94/ NKG2A-Qa-I system in the generation and function of ocular-induced splenic CD8+ regulatory T cells. Int Immunol 2008, 20:509-516.

19. Mingari MC, Ponte M, Bertone S, Schiavetti F, Vitale C, Bellomo R, Moretta A, Moretta L: HLA class I-specific inhibitory receptors in human $T$ lymphocytes: interleukin I5-induced expression of CD94/NKG2A in superantigen- or alloantigen-activated CD8+ T cells. Proc Natl Acad Sci USA 1998, 95: I I72-I I 77.

20. Gunturi A, Berg RE, Crossley E, Murray S, Forman J: The role of TCR stimulation and TGF-beta in controlling the expression of CD94/NKG2A receptors on CD8 T cells. Eur J Immunol 2005, 35:766-775

21. Guerra N, Benlhassan K, Carayol G, Guillard M, Pardoux C, Chouaib $S$, Caignard A: Effect of tumor growth factor-beta on NK receptor expression by allostimulated CD8+ T lymphocytes. Eur Cytokine Netw 1999, 10:357-364.

22. Derre L, Corvaisier M, Pandolfino MC, Diez E, Jotereau F, Gervois N: Expression of CD94/NKG2-A on human T lymphocytes is induced by IL- I 2: implications for adoptive immunotherapy. J Immunol 2002, 1 68:4864-4870.

23. Galiani MD, Aguado E, Tarazona R, Romero P, Molina I, Santamaria $M$, Solana R, Pena J: Expression of killer inhibitory receptors on cytotoxic cells from HIV-I-infected individuals. Clin Exp Immunol 1999, I I 5:472-476.

24. Jabri B, Selby JM, Negulescu H, Lee L, Roberts AI, Beavis A, LopezBotet $M$, Ebert EC, Winchester RJ: TCR specificity dictates CD94/NKG2A expression by human CTL. Immunity 2002, I 7:487-499. 
25. McKenna KC, Xu Y, Kapp JA: Injection of soluble antigen into the anterior chamber of the eye induces expansion and functional unresponsiveness of antigen-specific CD8+ T cells. Immunol 2002, I 69:5630-5637.

26. Ren Y, Yang P, Li B, Gao Y, Zhou H, Huang X, Zhu L, Kijlstra A: OVA-specific CD8+ T cells do not express granzyme $B$ during anterior chamber associated immune deviation. Graefes Arch Clin Exp Ophthalmol 2006, 244:1315-1321.

27. Cone RE, Li X, Sharafieh R, O'Rourke J, Vella AT: The suppression of delayed-type hypersensitivity by $C D 8+$ regulatory $T$ cells requires interferon-gamma. Immunology 2007, I 20: I I2-I I 9

28. Wang Y, Ghali WE, Pingle P, Traboulsi A, Dalal T, O'Rourke J, Cone RE: Splenic $T$ cells from mice receiving intracameral antigen suppress in-vitro antigen-induced proliferation and interferon-gamma production by sensitized lymph node cells. Ocul Immunol Inflamm 2003, I I:39-52.

29. Jiang L, Yang P, He H, Li B, Lin X, Hou S, Zhou H, Huang X, Kijlstra $A$ : Increased expression of Foxp3 in splenic CD8+ $T$ cells from mice with anterior chamber-associated immune deviation. Mol Vis 2007, I3:968-974.

30. Levings MK, Sangregorio R, Roncarolo MG: Human cd25(+)cd4(+) $t$ regulatory cells suppress naive and memory $T$ cell proliferation and can be expanded in vitro without loss of function. J Exp Med 200I, 193:1 295-1302.

31. Thornton AM, Shevach EM: CD4+CD25+ immunoregulatory $\mathbf{T}$ cells suppress polyclonal $\mathrm{T}$ cell activation in vitro by inhibiting interleukin 2 production. J Exp Med 1998, I 88:287-296.

32. Cosmi L, Liotta F, Lazzeri E, Francalanci M, Angeli R, Mazzinghi B, Santarlasci V, Manetti R, Vanini V, Romagnani P, Maggi E, Romagnani $S$, Annunziato F: Human CD8+CD25+ thymocytes share phenotypic and functional features with CD4+CD25+ regulatory thymocytes. Blood 2003, I 02:4I07-4I|4.

33. Gilliet M, Liu Y]: Generation of human CD8 $\mathrm{T}$ regulatory cells by CD40 ligand-activated plasmacytoid dendritic cells. J Exp Med 2002, 195:695-704.

34. Kang HK, Michaels MA, Berner BR, Datta SK: Very low-dose tolerance with nucleosomal peptides controls lupus and induces potent regulatory $\mathbf{T}$ cell subsets. $J$ Immunol 2005, I 74:3247-3255.

35. Myers L, Croft M, Kwon BS, Mittler RS, Vella AT: Peptide-specific CD8 T regulatory cells use IFN-gamma to elaborate TGFbeta-based suppression. J Immunol 2005, I 74:7625-7632.

36. Maile R, Pop SM, Tisch R, Collins EJ, Cairns BA, Frelinger JA: Lowavidity CD8lo $T$ cells induced by incomplete antigen stimulation in vivo regulate naive higher avidity CD8hi $\mathrm{T}$ cell responses to the same antigen. Eur J Immunol 2006, 36:397-4 I0.

37. Endharti AT, Rifa IMs, Shi Z, Fukuoka Y, Nakahara Y, Kawamoto Y, Takeda K, Isobe K, Suzuki H: Cutting edge: CD8+CDI22+ regulatory $\mathrm{T}$ cells produce IL- $\mathrm{O} 0$ to suppress IFN-gamma production and proliferation of CD8+ T cells. J Immunol 2005 , 1 75:7093-7097.

38. Hahn BH, Singh RP, La Cava A, Ebling FM: Tolerogenic treatment of lupus mice with consensus peptide induces Foxp3expressing, apoptosis-resistant, TGFbeta-secreting CD8+ T cell suppressors. J Immunol 2005, I 75:7728-7737.

39. Menoret A, Myers LM, Lee SJ, Mittler RS, Rossi RJ, Vella AT: TGFbeta protein processing and activity through TCR triggering of primary CD8+ $\mathbf{T}$ regulatory cells. J Immunol 2006, | 77:609|-6097.

40. Kezuka T, Streilein JW: In vitro generation of regulatory CD8+ $T$ cells similar to those found in mice with anterior chamberassociated immune deviation. Invest Ophthalmol Vis Sci 2000, 4I:|803-|8||

41. Peng Y, Shao H, Ke Y, Zhang P, Han G, Kaplan HJ, Sun D: Minimally activated CD8 autoreactive $T$ cells specific for IRBP express a high level of Foxp3 and are functionally suppressive. Invest Ophthalmol Vis Sci 2007, 48:2178-2I84.

42. Singh RP, La Cava A, Wong M, Ebling F, Hahn BH: CD8+ T cellmediated suppression of autoimmunity in a murine lupus model of peptide-induced immune tolerance depends on Foxp3 expression. J Immunol 2007, I 78:7649-7657.

43. Han G, Shao H, Peng Y, Zhang P, Ke Y, Kaplan HJ, Sun D: Suppressor role of rat CD8+CD45RClow $T$ cells in experimental autoimmune uveitis (EAU). J Neuroimmunol 2007, I 83:8|-88.

44. Ahmadzadeh M, Antony PA, Rosenberg SA: IL-2 and IL-I 5 each mediate de novo induction of FOXP3 expression in human tumor antigen-specific CD8 T cells. J Immunother (I 997) 2007, 30:294-302.

45. Eger KA, Sundrud MS, Motsinger AA, Tseng M, Van Kaer L, Unutmaz $D$ : Human natural killer $T$ cells are heterogeneous in their capacity to reprogram their effector functions. PLOS ONE 2006, I:e50.

46. Maeda M, Shadeo A, MacFadyen AM, Takei F: CDId-independent NKT cells in beta 2-microglobulin-deficient mice have hybrid phenotype and function of NK and T cells. J Immunol 2004, 172:6II5-6I22

47. Woo SY, Jung YJ, Ryu KH, Park HY, Kie JH, Im SA, Chung WS, Han $\mathrm{HS}$, Seoh JY: In vitro differentiation of natural killer $\mathbf{T}$ cells from human cord blood CD34+ cells. Br J Haematol 2003, I 2 | : | 48- I56.

48. Streilein JW, Niederkorn JY, Shadduck JA: Systemic immune unresponsiveness induced in adult mice by anterior chamber presentation of minor histocompatibility antigens. J Exp Med 1980, I52:|| $2|-| \mid 25$.
Publish with Biomed Central and every scientist can read your work free of charge

"BioMed Central will be the most significant development for disseminating the results of biomedical research in our lifetime. "

Sir Paul Nurse, Cancer Research UK

Your research papers will be:

- available free of charge to the entire biomedical community

- peer reviewed and published immediately upon acceptance

- cited in PubMed and archived on PubMed Central

- yours - you keep the copyright
BioMedcentral 